\title{
Conditions of the Internal Microclimate in the Museum
}

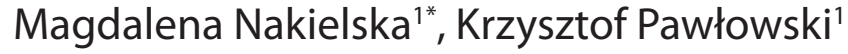 \\ 1 UTP University of Science and Technology in Bydgoszcz, Faculty of Civil and Environmental Engineering and \\ Architecture, Al. prof. S. Kaliskiego 7, 85-796 Bydgoszcz \\ * Corresponding author's e-mail: magdalena.nakielska@gmail.com
}

\begin{abstract}
The interior microclimate is a collection of all physical and chemical parameters of rooms affecting the human body, objects and a building. The values of these parameters are directly influenced by the type of installations in the building, such as heating, ventilation and lighting. While shaping the internal environment of the museum building, we should include the requirements of the exhibits and the comfort of people staying in the room, simultaneously reducing energy consumption. This article is a case study of a chosen museum including the measurements of the parameters shaping the interior microclimate.
\end{abstract}

Keywords: interior microclimate, microclimatic conditions, physical air parameters

\section{INTRODUCTION}

Recently, energy-efficient construction has become a trend in building engineering. Legal regulations and the investors' awareness force designers to make use of modern technological and material solutions. The innovative solutions influence the internal conditions of rooms where we live, work or indulge in a hobby. The quality of the internal air becomes an important issue because we spend all day in a closed space. As a result, the research on the microclimate of spaces is conducted more frequently. The microclimate of a room consists of various factors that characterize the air condition in a closed space. The most important ones are thermal elements of the microclimate: air temperature, air humidity, air movement velocity and surface temperature of barriers. Their values and reciprocal correlation at a given moment decide about that if the users feel well in a particular room or if they feel any discomfort. We care about comfort of people visiting museums but, in particular, we should pay attention to the exhibits in the museum. The materials used to create the exhibits are very sensitive to environmental conditions. Correct parameters should be chosen and the presence of risk factors, which will cause the degradation of material structure, should be minimized.

The aim of this article is to present the part of the researches on the microclimate of exhibit spaces of the Department of Archeology of the Leon Wyczółkowski District Museum in Bydgoszcz, with the emphasis on the air relative humidity and its influence on the microclimate. The major restoration work procedure aiming at the conservation of antique exhibits is to control the relative humidity. Uncontrolled changes of this parameter may lead to irreversible damages of the exhibits and may cause discomfort of the workers and visitors.

\section{Factors shaping the microclimate of the museum spaces}

The museum spaces require a careful choice of the physical and chemical parameters influencing the construction of the building, museum collections and people staying in those spaces. The following factors have a direct influence on the microclimate of the museum interiors. 


\section{Air relative humidity}

The air relative humidity is one of the parameters that have the greatest importance while setting the conditions of storing items of a historical value. A lot of materials, which were used to make the elements of the exhibits, may degrade because of absorption or desorption of the moisture from the air. These processes may cause damage, especially to organic materials such as: paper, wood, fabric, hide, bones, horns. Not only the level of humidity but also its large fluctuations lead to devastation of the exhibits. Too low relative humidity makes the materials more fragile, breakable or stiff, they warp, crack, brittle and shrink. On the other hand, too high relative humidity causes the decline of material flexibility, the elements are deformed, the mechanical damage resistance is lowered and the sensitivity to fungi and bacteria development is higher. It results in glues and bonds dissolving, metallic corrosion, paint decay, cracking and clouding of glass. The Polish standard [PN-EN 15757:2012P] includes material classification in relation to their sensitivity to the air relative humidity [Charkowska 2007].

\section{Air temperature}

Maintaining an appropriate level of the air temperature in the museum spaces is significant for two reasons. Firstly, the relative humidity depends on the air temperature, which has a direct influence on the collection of exhibits in the building. Secondly, it is important to provide thermal comfort for the museum employees and visitors. Appropriately chosen heating and ventilation system in rooms shape the temperature parameter. Those systems have to react to the variable inner and outer conditions. The variability of inner conditions is mainly caused by heat and moisture gains coming from the people visiting the museum spaces, and heat gains coming from the outside.

In order to form the optimum inner climate conditions for different kinds of exhibits, the European Federation of HVAC National Association has come up with a set of recommendations to create safe environment [Santoli de 2008]. Table 1 shows recommended values of the temperature and the air relative humidity for chosen items and materials.

Depending on the reciprocal relations between the temperature and the air relative
Table 1. Recommended values of the temperature and air relative humidity - REHVA project

[Santoli de 2008]

\begin{tabular}{|c|c|c|}
\hline \multirow[t]{2}{*}{ Item / Material } & $\begin{array}{l}\text { Air relative } \\
\text { humidity }\end{array}$ & $\begin{array}{c}\text { Air } \\
\text { temperature }\end{array}$ \\
\hline & $\%$ & ${ }^{\circ} \mathrm{C}$ \\
\hline Iron armour, weapon & $<40$ & \\
\hline Bones, ivory & $45-65$ & $19-24$ \\
\hline Bronze & $<55$ & \\
\hline Paper & $50-60$ & $19-24$ \\
\hline Anatomic collection & $40-60$ & $19-24$ \\
\hline $\begin{array}{l}\text { Minerals collection, stone, } \\
\text { marble }\end{array}$ & $45-60$ & $<30$ \\
\hline Leather, hide, parchment & $50-60$ & \\
\hline $\begin{array}{l}\text { Botanical collection (including } \\
\text { herbs) }\end{array}$ & $40-60$ & \\
\hline Oriental lacquer & $50-60$ & $19-24$ \\
\hline Wood & $40-65$ & $19-24$ \\
\hline $\begin{array}{l}\text { Painting on wood, polychrome } \\
\text { wood }\end{array}$ & $45-65$ & $19-24$ \\
\hline Books, manuscripts & $50-60$ & $19-24$ \\
\hline Ethnographic materials & $40-60$ & $19-24$ \\
\hline Organic materials (generally) & $50-65$ & $19-24$ \\
\hline Plastics & $30-50$ & \\
\hline $\begin{array}{l}\text { Polished metals and alloy, } \\
\text { brass, sliver, tin, lead, copper }\end{array}$ & $<45$ & \\
\hline Gold & $<45$ & \\
\hline Papyrus & $35-40$ & $19-24$ \\
\hline Fur and leather & $45-60$ & $15-21$ \\
\hline Paintings on canvas & $35-50$ & $19-24$ \\
\hline $\begin{array}{l}\text { China, ceramics*, stoneware, } \\
\text { earthen goods }\end{array}$ & $20-60$ & \\
\hline
\end{tabular}

humidity, some problems connected with maintaining the exhibits in a good state may occur. A high temperature and low air relative humidity cause drying and fragmenting of some materials, for example: leather, parchment, paper and glues. A high temperature and high air relative humidity create favourable conditions for microbial development and conditions for insects and rodents. The temperature below $10^{\circ} \mathrm{C}$, high air relative humidity and poor air circulation lead to moistness and microbial development [Charkowska 2007].

\section{Air pollution}

The protection of exhibits against the threats connected with the air quality is as important as maintaining appropriate air parameters, such as temperature and humidity. Since exceeding the concentration of some gas contamination of the air causes irreversible changes in the museum 
collections, it is necessary to set permissible pollution values depending on the material. Charkowska [2016] presents recommended concentration of the air pollution. Air pollution causes corrosion, discoloration or changes in the colour of stone objects and paints, brittleness or damages on the surface of items.

\section{Lighting}

The exhibits in the museum are exposed to different kinds of radiation: visible and black light, natural and induced. The influence of the lighting on the changes in the material is different, depending on the length of exposition and the material which the element is made of. In fact, all kinds of waves have oxidative properties, which results in changes in the colour of dye, bringing on material aging, brittleness and cracking of paper, fabric and painterly layers. The rooms, where the exhibits will be stored or presented, should be appropriately prepared. The windows should be equipped with the UV filters or foils ensuring protection from the light rays. At the museum expositions, the lighting should be kept at the level of 50-200 lux, depending on the types of buildings, in warehouses - to 150 lux. The light sources should not emit harmful radiation or lighting fittings should be equipped with UV and IR filters. Recommended light bulbs are the ones with the tag: UV STOP [Święcka and Łukomski 2013].

\section{Research methodology}

The Leon Wyczółkowski District Museum, archeological collections in Bydgoszcz, Mennica Street 2 (Fig. 1) was chosen to check the parameters of the internal air in the museum. This is a two-tier building with the basement and the attic. The building was constructed after 1789 and was called the White Granary. Originally, it functioned as a reloading granary and the grain warehouse for the nearby mills. Since 2009, the White Granary has been used for archeological collections of the District Museum. The building has a frame construction. The construction of the walls includes: wattle and daub with the thickness of $6 \mathrm{~cm}$, highly vapour-permeable foil, mineral wool with the thickness of $10 \mathrm{~cm}$, polyethylene foil, gypsum boards. The walls have not been thermally modernized. The building has old window woodwork. There are mainly areas of exposition spaces, office and break rooms. The

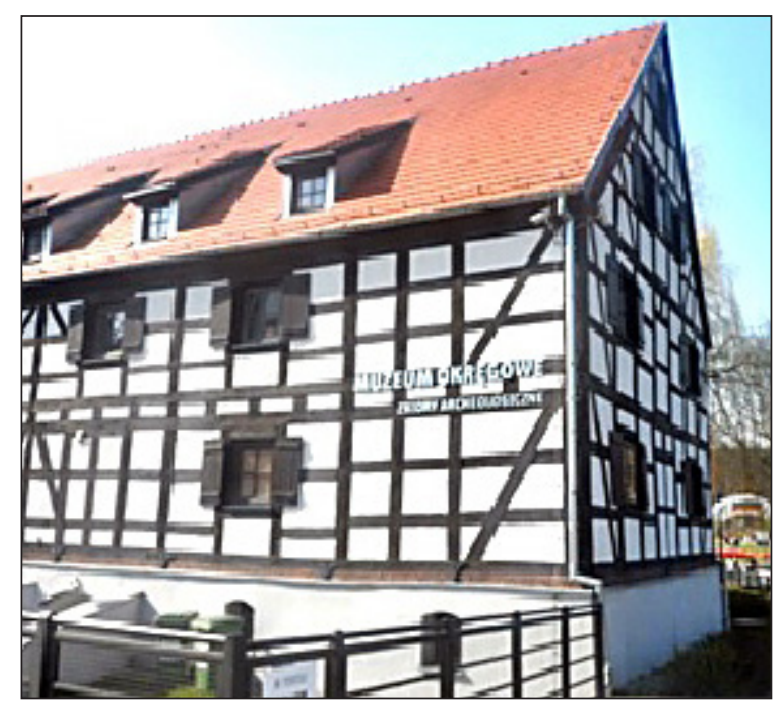

Fig. 1. District Museum in Bydgoszcz

museum collections are mostly wooden, leather and metal elements. In many places, the exposition is secured with glass which facilitates keeping appropriate air parameters. Figure 2 presents an example of the exposition. The roof supporting structure is a wooden construction, insulated with mineral wool with the thickness of $20 \mathrm{~cm}$. Heat is supplied to the building from the district heating network.

During taking the measurements of the air parameters inside the rooms, some windows were open (but not all the time), all were covered with shades, the lighting and the ventilation at the exhibition were on, the computer at the counter and all the screens at the exposition were turned on. The measurement had been taken hourly since the opening of the museum. It was taken about 1 meter above the level of the floor. 8 representative points were chosen on the ground floor and

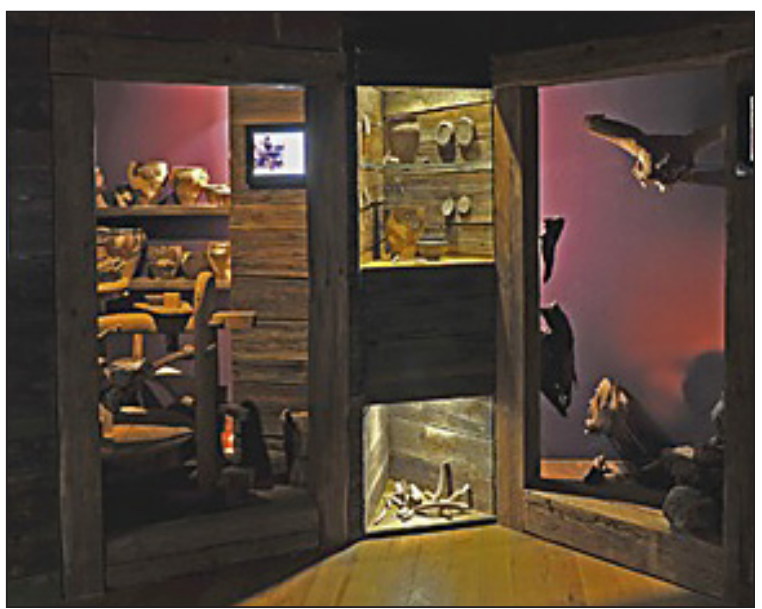

Fig. 2. Exhibition of archaeological collections 
9 measuring points were on the first floor. The first measurement was taken at 11.30 a.m. and the last - at 5.30 p.m. Three measuring days were chosen: $23^{\text {rd }}$ June 2018 with an average temperature of the external air of $21.3^{\circ} \mathrm{C}$ and the humidity of $56 \%, 24^{\text {th }}$ June 2018 with an average temperature of the external air of $17.6{ }^{\circ} \mathrm{C}$ and the humidity of $57 \%$, and $26^{\text {th }}$ June 2018 with an average temperature of the external air of $21.1{ }^{\circ} \mathrm{C}$ and the humidity of $59 \%$.

The measurements were taken by means of Delta OHM HD32.3 meter (Fig. 3) with three probes: globe thermometer, hygrometer and anemometer.

\section{Measurement results}

The measurement of the air flow velocity showed the results, on average, from $0.02 \mathrm{~m} / \mathrm{s}$ to $0.08 \mathrm{~m} / \mathrm{s}$. There was some local disturbance of the air velocity caused by opened windows, and that is why, these results were excluded from the analysis as unreliable.

The measurement results of the temperatures and the air relative humidity in a chosen museum building are presented in Table 2.

On the basis of the above results, a relative humidty graph was drawn for three measuring days (Fig. 4).

Taking into consideration the data from Table 1 and the conclusions from the observation of the museum exposition, it can be specified that the temperature of the internal air should be between

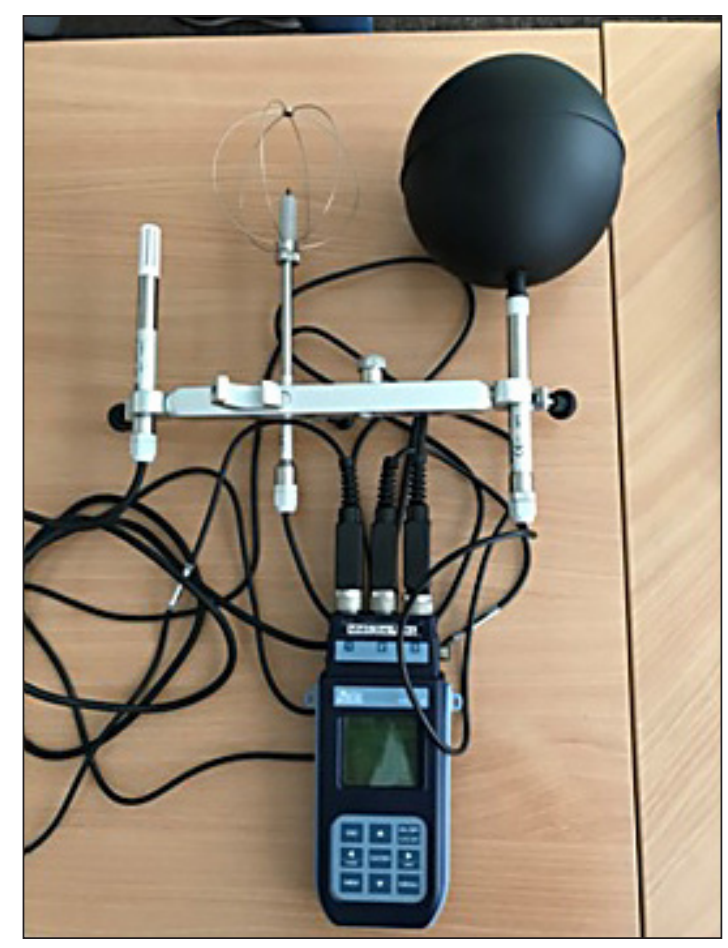

Fig. 3. Delta OHM HD32.3 meter

$19-24^{\circ} \mathrm{C}$ and the relative humidity should fluctuate between $40-60 \%$. On the grounds of presented measurement results (Table 2 and Fig. 4), it can be stated that these values slightly diverge from the desirable ones. The air relative humidity on the first day of the measurement did not reach the value of $40 \%$, yet the difference is minor. The average temperature of the air slightly exceeded recommended maximum value.

Table 2. Measurement results of average temperatures and the humidity of the internal air - own elaboration

\begin{tabular}{|c|c|c|c|c|c|c|c|c|}
\hline \multirow{2}{*}{\multicolumn{2}{|c|}{$\begin{array}{l}\text { Data and the location of } \\
\text { measuring points }\end{array}$}} & \multicolumn{7}{|c|}{ Measurement hours } \\
\hline & & 11.30 & 12.30 & 13.30 & 14.30 & 15.30 & 16.30 & 17.30 \\
\hline \multirow{3}{*}{$\begin{array}{l}\text { Temperature, } \\
\text { points on the } \\
\text { ground floor }\end{array}$} & 23.06 .18 & 24.31 & 24.70 & 24.44 & 24.53 & 24.66 & 24.66 & 24.58 \\
\hline & 24.06 .18 & 23.91 & 24.43 & 24.48 & 24.54 & 23.65 & 24.34 & 24.28 \\
\hline & 26.06 .18 & 24.28 & 24.16 & 24.36 & 24.34 & 24.59 & 24.68 & 24.76 \\
\hline \multirow{3}{*}{$\begin{array}{l}\text { Temperature, } \\
\text { points on the } \\
\text { first floor }\end{array}$} & 23.06 .18 & 24.58 & 24.26 & 23.63 & 23.63 & 24.14 & 24.26 & 24.13 \\
\hline & 24.06 .18 & 24.22 & 24.41 & 24.31 & 24.26 & 24.27 & 24.52 & 24.31 \\
\hline & 26.06 .18 & 23.94 & 23.96 & 24.21 & 24.20 & 24.34 & 24.38 & 24.50 \\
\hline \multirow{3}{*}{$\begin{array}{l}\text { Humidity, } \\
\text { points on the } \\
\text { ground floor }\end{array}$} & 23.06 .18 & 38.78 & 35.91 & 36.40 & 36.01 & 37.53 & 37.53 & 38.38 \\
\hline & 24.06 .18 & 42.96 & 42.26 & 42.26 & 42.14 & 42.38 & 43.11 & 43.11 \\
\hline & 26.06 .18 & 46.94 & 43.16 & 40.70 & 45.20 & 42.71 & 39.94 & 41.25 \\
\hline \multirow{3}{*}{$\begin{array}{l}\text { Humidity, points } \\
\text { on the first floor }\end{array}$} & 23.06 .18 & 38.70 & 37.08 & 37.98 & 37.98 & 37.59 & 37.87 & 39.64 \\
\hline & 24.06 .18 & 41.77 & 42.60 & 42.89 & 42.39 & 42.09 & 41.98 & 42.41 \\
\hline & 26.06 .18 & 46.68 & 43.90 & 43.36 & 45.06 & 43.11 & 41.47 & 41.87 \\
\hline
\end{tabular}




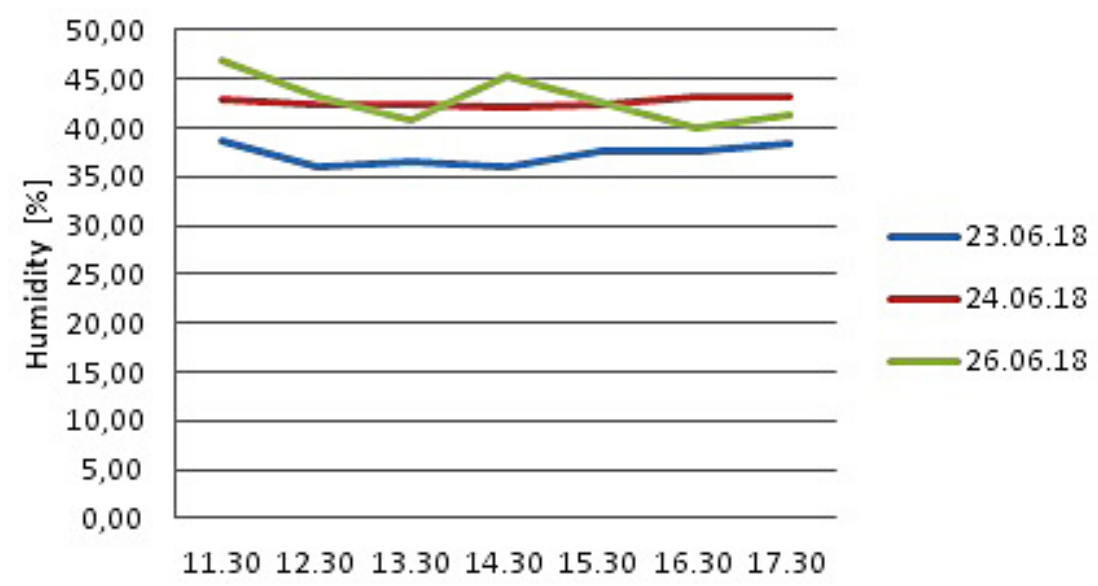

Fig. 4. Relative humidity graph

\section{CONCLUSIONS}

Planning, constructing and using museum buildings is a complex process and requires the knowledge of a great deal of issues related to conservation of exhibits, monuments, structural installations, general construction of buildings and construction physics. In the building where we can find collections sensitive to the internal microclimate, a correctly designed heating and ventilation system is a significant design task and a great challenge to meet the expected requirements. In the analysed building, basic air parameters, such as the temperature and the humidity, were maintained at a required level. However, there was not any detailed research on the remaining parameters of the microclimate influencing the conditions in which the item is exposed.

\section{REFERENCES}

1. Charkowska A. 2007. Microclimate in museum buildings (part.1). Refrigeration and air conditioning. 3, 36-43. (in Polish).

2. Charkowska A. 2016. Shaping the microclimate in museums, archives and art magazines (part 2). Refrigeration and air conditioning. 12 (in Polish).

3. PN-EN 15757:2012P, Conservation of cultural property - specifications for temperature and relative humidity climate - induced mechanical damage in organic hygroscopic materials (in Polish).

4. Santoli de, L. 2008. Indoor Environment Engineering (IEE) in cultural heritage - a REHVA guidebook. Workshop. (in Polish).

5. Święcka E., Łukomski M. 2013. Climate management in museums: collections protection and energy saving. Harvest protection vol. 3. The publishing series of the National Institute of Museology and Collections Protection (in Polish). 